\title{
Peran Pengembangan dan Pemanfaatan Teknologi Pendidikan
}

\author{
Agra Pratama Satya ${ }^{1}$, Nurul Iman ${ }^{2}$, dan Zul Anwar ${ }^{3}$ \\ 1,2,3 Fakultas Ilmu Pendidikan dan Psikologi Undikma Mataram \\ Email: agraowey@gmail.com
}

\section{PENDAHULUAN}

Teknologi adalah keseluruhan sarana untuk menyediakan barang-barang yang diperlukan bagi kelangsungan dan kenyamanan hidup manusia. Penggunaan teknologi oleh manusia diawali dengan pengubahan sumber daya alam menjadi alat-alat sederhana. Penemuan prasejarah tentang kemampuan mengendalikan api telah menaikkan ketersediaan sumbersumber pangan, sedangkan penciptaan roda telah membantu manusia dalam bepergian dan mengendalikan lingkungan mereka. Perkembangan teknologi terbaru, termasuk di antaranya mesin cetak, telepon, dan Internet, telah memperkecil hambatan fisik terhadap komunikasi dan memungkinkan manusia untuk berinteraksi secara bebas dalam skala global. Tetapi, tidak semua teknologi digunakan untuk tujuan damai. Pengembangan senjata penghancur yang semakin hebat telah berlangsung sepanjang sejarah dari pentungan sampai senjata nuklir.

\section{PEMBAHASAN}

\section{A. Pengertian Teknologi}

Assoiation for educational kominiation an technology (1980) mendefinisikan eknologi pendidikan sebagai berikut:

Teknologi pendidikan adalah suatu proses kompleks yang terintergrasi meliputi manusiA, prosedur, ide dan peralatan dan organisasi untuk menganalisis masalah yang mencakup semua aspek belajar, serta meranang, melaksanakan, menilai dan mengelola pemeahan masalah itu. [1]

Dengan demikian, secara umum teknologi pendidikan diarikan sebagai media yang lahir direvolusi teknologi komunikasi yang dapat digunakan untuk tujuan pengajaran pengajaran, disamping guru, buku dan papan tulis. Kemudian Nasuion (1982) Juga mengungkapkan, pada hakikatnya teknologi pendidikan adalah suatu pendekatan yang sistematis dan kritis tentang pendidikan. Teknologi pendidikan memandang soal mengajar dan belajar sebagai suatu masalah atau problema yang harus dihadapi seara rasional dan ilmiah.[2]

Oleh karena iu langkah yang terpenting dalam rangka kegiatan belajar mengajar, tidak semata mata media teknologi komunikasi yang rumit dan kompleks.

\section{B. Dasar Pemikiran Teknologi Pendiddikan}

Dasar Pemikiran Teknologi Pendiddikan dapat di tinjau dari tujuan pendidikan, taiu mengubah anak dan cara berpikir dan marasa berbuat, jadi mengubah kelakuan. Kurikulum disusun untuk mendorong anak berkembang ke arah tujuan itu. sudah selayaknya pendidik maupun anak didik harus tahu apa yang harus dicapai. atau tegasnya harus diketahui dengan jelas apa yang dapat dilakukan oleh murid sebagai hasil pelajaran yang tidak dapat dilakukannya sebelum ia mempelajarinya. Perkembangan ilmu pengetahuan telah membawa perubahan yang sangat signifikan terhadap berbagai dimensi kehidupan manusia, baik dalam ekonomi, sosial, budaya maupun pendidikan. Oleh karena itu agar pendidikan tidak tertinggal dari perkembangan iptek tersebut, perlu adanya penyesuain-penyesuaian, terutama sekali yang berkaitan dengan faktor-faktor pengajaran disekolah. Salah satu faktor tersebut adalah media pembelajaran berbasis teknologi yang perlu dipelajari dan dikuasai guru/calon guru, sehingga mereka dapat menyampaikan materi pelajaran kepada para siswa secara baik berdaya guna dan berhasil guna. 
Seiring dengan berkembangnya pendidikan dan sistem pendidikan di Indonesia, seluruh elemen masyarakat, utamanya yang terkait langsung dengan pendidikan dituntut untuk lebih kreatif dan profesional untuk mengembangkan pendidikan. Selain itu, para pelaku pendidikan juga diharapkan sesuai dengan prosedur yang telah ditetapkan bersama sesuai dengan kebutuhan dan tantangan pendidikan. Kesadaran tentang pentingnya pendidikan dan teknologi yang dapat memberikan harapan dan kemungkinan yang lebih baik di masa mendatang, telah mendorong berbagai upaya dan perhatian seluruh lapisan masyarakat terhadap setiap gerak dan langkah, dalam perkembangan dunia pendidikan.

Pendidikan sebagai salah satu upaya dalam meningkatkan kualitas hidup, pada intinya bertujuan untuk memanusiakan manusia, mendewasakan, serta merubah prilaku dan meningkatkan kualitas hidup. Seperti dijelaskan dalam al-quran surat Al-Mujadalah ayat 11 yang berbunyi: "Niscaya Allah akan meninggikan orang-oran yang beriman diantara kamu, dan beberapa orang, yang diberi ilmu pengetahuan beberapa derajat, dan Allah maha mengetahui apa yang kamu kerjakanQS. Al-Mujadalah:11). Untuk itulah perlu adanya cara atau metode untuk menjawab tangtangan - tantangan yang muncul seiring dengan berkembangnya waktu, dan dan bagaimana pencapain kurikulum secara maksimal, maka dari itu peranan penting teknologi sangatlah penting dalam pencapaian pendidikan yang maksimal, dan khususnya yang berkaitan dengan pendidikan agama islam.

Dengan pendekatan teknologi pendidikan, kita dapat menggunakan metode ilmiah untuk menguji-cobakan hipotesis-hipotesis tentang cara yang paling efektif guna mencapai suatu tujuan yang telah ditentukan. Usaha ini pada hakikatnya tidak berbeda dengan metode pemecahan masalah (method of problem solving) yang dilakukan dalam bidang lainnya.

Dalam garis besar, langkah-langkah yang diikuti dalam metode teknologi pendidikan adalah:

1. Merumuskan tujuan yang jelas yang harus dicapai yang dapat dipandang sebagai masalah.

2. Menyajikan pelajaran menurut cara dianggap serasi yang kita pandang sebagai "hipotesis"yang perlu dites.

3. Menilai hasil pelajaran untuk memuji hipotesis itu.

4. Mencari perbaikan andaikan hasilnya belum memenuhi syarat atau standar yang ditentukan dan melangsungkan percobaan dengan cara lain sampai tercapai apa yang diharapkan. [3]

Teknologi pendidikan mengharuskan guru merumuskan tujuan yang jelas memikirkan metode yang dianggapnya paling efektif untuk mencapai tujuan itu. Tujuan yang jelas merupakan pegangan untuk memilih metode yang tepat. Banyak guru yang masuk kelas tanpa mengetahui dengan jelas apa yang ingin dicapainya dalam jam pelajaran itu.tanpa tujuan yang jelas kita tak kan tahu ke mana kita pergi dan apakah kita sampai ke tempat yang diharapkan, proses pembelajaran pada satuan pendidikan sekolah dasar.

Seorang harus memperhatikan karakteristik anak yang akan menghayati pengalaman belajar tersebut sebagai satu kesatuan yang utuh. Pengemasan pembelajaran harus dirancang secara tepat karena akan berpengaruh terhadap kebermaknaan pengalaman belajar anak. Pengalaman belajar yang menunjukkan kaitan unsur-unsur konseptual baik di dalam maupun antar matapelajaran, akan memberi peluang bagi terjadinya pembelajaran yang efektif dan lebih bermakna.

Selanjutnya teknologi pendidikan menuntut agar diadakan penilaian yang segera tentang apa yang telah dipelajari. Banyak guru yang melakukan hanya beberapa kali dalam satu semester dalam bentuk ulangan. Penilaian yang segera setelah pelajaran ,memberikan keterangan tentang prestasi anak dan sekaligus tentang kemampuan metode penyajian guru. Penilaian itu berfungsi sebagai :

(1) Alat mengukur hasil belajar murid.

(2) Alat bagi guru untuk menilai efekviitasnya mengajar

(3) Titik tolak untuk memperbaiki prestasi anak dengan menganalisis

kesalahan-kesalahan yang mereka perbuat serta memperbaiki

metodenya mengajar.[4]

Bila guru menerapkan prinsip-prinsip teknologi pendidikan secara konsekuen, maka terbuka jalan untuk memperbaiki mutunya sebagai guru, ia akan memandang proses 
mengajar mengajar sebagai problema yang tak berkesudahan yang dihadapinya secara obyektif dan ilmiah. Dengan sikap serta usaha demikian mengajar akan dapat dikembangakan dan ditingkatkan menjadi profesi dalam arti yang sebenarnya. Langkahlangkah dalam tegnologi pendidikan seperti digambarkan pada bagan itu dapat digunakan sebagai pedoman untuk menyusun program suatu lembaga pendidikan tapi juga merencanakan suatu pelajaran bahkan untuk memecahkan tiap masalah pengajaran yang suwaktu-waktu timbul dalam kelas, misalnya pertanyaan murid tentang suatu yang kurang dipahaminya. Dalam menghadapi masalah mengajar-belajar guru harus berfikir: Apa tujuanya? Apa yang harus dapat dilakukan oleh murid? Bagamaina cara mencapai tujuan itu ? Bagaimana hasilnya? Bagaimana hasilnya? Bila tidak memuaskan bagaimana cara memperbaikinya?. Inilah beberapa hal yang harus di dikuasai oleh seorang pendidik.

\section{Pengembangan Teknologi}

Tampak konsep teknologi pengajaran merupakan gejala baru di dalam dunia pendidikan dan latihan. Namun, bahwasanya konsep dasarnya telah berkembang sejak berabad- abad dari hasil pemikiran dari konsep konsep pengajaran sebelumnya.

Perkembangan dari berbagai metode pengajaran saat ini merupakan tanda lahir teknologi. Sekalipun dari latar belakang sejarahnya, tidak berdasarkan ilmu pengetahuan seperi yang kita ketahui. Dalam metode pengajaran terkandung konsep konsep yang mempengaruhi cara berfikir, bertindak, penelitian dan pengembangan pembelajaran yang kemudian dikenal sebagai teknologi.[5]

Pengembangan jaringan informasi 'merupakan upaya mendasar yang perlu disegerakan kepada masyarakat kalangan bawah, seperti kelompok rumah tangga miskin, rentan, takberdayal adalah kelompok sasaran yang paling diutamakan. Karena dengan cepat perkembagan teknologi dari,teknologi cetak, teknologi audio-visual dan Pada 1930-an felm mulai digunakan untuk kegiatan pembelajaran[6], teknologi berbasis komputerdan teknologi terpadu. [7]

Dalam pengembagan Teknologi dapat dikelompokkan menjadi teknologi rendah, sedang, atau teknologi tinggi. Teknologi rendah tidak menggunakan kelistrikan; yaitu tidak perlu dicolok dan tidak juga membutuhkan baterai. Sebagai misal, sebuah kaca pembesar untuk memperbesar bahan-bahan cetakan bagi siswa yang terhambatan secara penglihatan digolongkan teknologi pembantu berteknologi rendah.

Teknologi menengah membutuhkan kelistrikan. Buku mini berpendar untuk meningkatkan pencahayaan merupakan contoh teknologi menengah. Teknologi tinggi melibatkan penggunaan komputer. Membaca kurzweil merupakan contoh dari teknologi pembantu berteknologi tinggi.[8]

\section{Pemanfaatan Teknologi}

Sudah selayaknya lembaga - lembaga pendidikan yang ada segera memperkenalkan dan memulai penggunaan dan memanfa'atkan teknologi informasi dan komunikasi (TIK) sebagai basis pembelajaran yang lebih mutakhir. Hal ini penting, mengingat penggunaan TIK merupakan salah satu faktor penting yang memungkinkan kecepatan transformasi ilmu pengetahuan kepada para peserta didik, generasi bangsa ini secara lebih luas.

Dalam konteks yang lebih spesifik, dapat dikatakan bahwa kebijakan penyelenggaraan pendidikan, baik yang diselenggarakan oleh pemerintah, pemerintah daerah, maupun masyarakat harus mampu memberikan akses pemahaman dan penguasaan teknologi mutakhir yang luas kepada para peserta didik. Progam pembangunan pendidikan yang terpadu, terarah dan berbasis teknologi paling tidak akan memberikan multiplier effect dan nurturing effect terhadap hampir semua sisi pembangunan pendidikan sehingga TIK berfungsi untuk memperkecil kesenjangan penguasaan teknologi mutakhir, khususnya dalam dunia pendidikan.

Pembangunan pendidikan berbasis TIK setidaknya memberikan dua keuntungan. Pertama, sebagai pendorong komunita pebdidikan (termasuk guru) unuk lebih apresiatif dan proaktif dalam maksimalisasi potensi pendidikan. Kedua, memberikan kesempatan luas kepada 
peserta didik dalam memanfaatkan setiap potensi yang ada, yang dapat diperoleh dari sumber - sumber yang tidak terbatas.

Adapun kedudukan lain TIK dalam pendidikan, yaitu :

Mempermudah kerjasama antar Pelajar dan Pendidik, menghilangkan batas ruang, jarak, dan waktu.

Sharing information, sehingga hasil penelitian dapat digunakan bersama - sama dan mempercepat pengembangan ilmu pngetahuan.

\section{PENUTUP}

Dari pemaparan diatas, teknologi pendidikan dapat di tafsirkan sebagai media dari perkembangan alat komunikasi yang dugunakan untuk tujuan pendidikan. Alat-alat itu lazim disebut "hard ware". Ada pula yang memandang teknologi pendidikan sebagai suatu pendekatan yang ilmiah kritis, dan sistematis tentang pendidikan. Pendirian ini mengutamakan "soft ware"-nya. Tanpa alat-alat, pendidikan dapat dijalankan. Sebaliknya "hard ware" tak berguna tanp "soft ware".

Teknologi pendidikan merupakan suatu ekspresi dari gerakan dan teknologi pendidikan mengajak guru untuk bersikap problematis terhadap proses belajar mengajar serta memandang tiap metode metode mengajar sebagai hipotesis yang harus di uji efektivitasnya.dengan demikian teknologi pendidikan mendorong profesi keguruan untuk berkembang menjadi "science". Namun pekerjaan guru akan selalu mengadung aspek"seni".

Dari pemaparan diatas, teknologi yang paling penting adalah teknologi yang ditimbulkan dari diri pendidik, tanpa seorang pendidik yang handal dan kreatif maka teknologi tidak akan bermanfaat dalam pendidikan. Kerena pada dasarnya kesuksesan dalam pendidikan adalah terletak pada keaktifan seorang pendidik dalam mengelolah lingkunagan sekolahnya. Dan seorang Guru harus berwawasan luas, memiliki kreativitas tinggi, keterampilan metodologis yang handal, rasa percaya diri yang tinggi dan berani mengemas dan mengembangkan materi Secara akademik, guru dituntut untuk terus menggali informasi ilmu pengetahuan yang berkaitan dengan materi yang akan diajarkan dan banyak membaca buku agar penguasaan bahan ajar tidak terfokus pada bidang kajian tertentu saja, serta seorang guru harus menguasai teknologi dengan sepenuhnya.

Serta seorang peserta didik memerlukan bahan bacaan atau sumber informasi yang cukup banyak dan bervariasi, dan juga fasilitas internet. Semua ini akan menunjang, memperkaya, dan mempermudah pengembangan wawasan. Bila sarana ini tidak dipenuhi, maka seorang guru harus lebih kreatif.

\section{DAFTAR PUSTAKA}

1. Danim, Sudarman. Media Komunikasi Pendidikan. Jakarta: Bumi Aksara. 1995.

2. Nasution. Teknologi Pendidikan Jakarta: Bumi Aksara. 1994.

3. Sudjana, Nana. Ahmad Rifai. Teknologi Pengajaran. Bandung: SBA. 2003.

4. Wasty Sumanto. Teknologi Pendidikan. Jakarta: Renika Cipta. 2009.

5. Sharo E. Smaldino, Debora L. Lother, jemesde Russel. Teknologi Pewmbelajaran Dan Media Pembelajaran. Jakarta: kjencana, 2012 Cyril Poster. Gerakan Menciptakan Sekolah Unggulan,Jakarta: Adidaya. 2000.

6. Dermawan, Deni. Teknologi Pembelajaran Bandung: PT Remaja Rosdakarya. 2011.

7. Hadi, Yusuf. Menyemai Benih Teknologi Pendidikan. Jakarta: Mahkota. 2000. 